\title{
Assessment of quality of life among caregivers of persons with permanent disabilities attending rehabilitation centre in H. D. Kote Taluq, Mysore district, Karnataka, India
}

\author{
Prakash Boralingiah $^{1 *}$, Arun Baby ${ }^{2}$, Praveen Kulkarni $^{1}$, Seetharam M. Ramachandrappa ${ }^{3}$, \\ Renuka Manjunath ${ }^{1}$
}

\begin{abstract}
${ }^{1}$ Department of Community Medicine, Jagadguru Sri Shivarathreeswara University, Mysore, Karanataka, India ${ }^{2}$ Department of Virus Research, Manipal Centre for Virus Research, Manipal, Karnataka, India

${ }^{3}$ Consultant Orthopaedic Surgeon, Head of Health Activities, SVYM, Sargur, Karnataka, India
\end{abstract}

Received: 22 July 2016

Accepted: 19 August 2016

\section{*Correspondence:}

Dr. Prakash Boralingiah,

E-mail: prakashdr90@yahoo.com

Copyright: ( $)$ the author(s), publisher and licensee Medip Academy. This is an open-access article distributed under the terms of the Creative Commons Attribution Non-Commercial License, which permits unrestricted non-commercial use, distribution, and reproduction in any medium, provided the original work is properly cited.

\begin{abstract}
Background: Quality of life (QoL) is defined as "an individual's perception of their position in life in the cultural context and in the value systems in which they live and in relation to their goals, expectations, concerns and desires. Caregivers of persons with chronic health conditions run the risk of emotional distress and poor adjustment to the demands of the patient, which in turn may adversely affect the quality of care that a person in need would receive. An assessment of quality of life among caregivers is important, for interventions targeted at rehabilitation.

Methods: A 100 caregivers of persons with disability registered under the rehabilitation program of SVYM at VMH Saragur were selected for the study. WHOQOL-BREF questionnaire was used to assess quality of life of caregivers.

Results: The Mean age of the caregivers was found to be 38.25 years with 87 (87\%) females and 13 (13\%) males. The mean Quality of Life of these caregivers was 71.97. Physical domain was significantly associated with income, earning capacity and duration of care. Psychological domain was associated with income and family type. Social domain was the most affected, with factors viz. Age $(p$-value $=0.002)$, employment ( $p$-value $=0.02)$, earning capacity ( $p$-value $=0.032$ ), education and duration of care being significantly associated. Environmental domain was associated with relation to caregiver, earning capacity ( $\mathrm{p}$-value $=0.032$ ), education and income. Marital status was observed to affect all the domains.

Conclusions: The Quality of Life of Caregivers was significantly affected by a multitude of factors which need to be addressed to ensure proper care of their wards. Interventions aimed at building the capacities the affected individuals as well as the caregivers would be highly beneficial to both groups.
\end{abstract}

Keywords: Caregivers, WHOQOL-BREF questionnaire and quality of life

\section{INTRODUCTION}

Disability is any restriction or lack (resulting from an impairment) of ability to perform an activity in the manner or within the range considered normal for a human being. Disabilities are of five types namely locomotor, visual, hearing, speaking and mental disabilities. ${ }^{1}$ The National Sample Survey Organization (NSSO) estimated the number of persons with disabilities in India at $1.8 \%$ (49-90 million), and $75 \%$ of disabled live in rural areas. ${ }^{2}$ The physical and mental well-being of a caregiver is important for the well-being of the person 
receiving care. Caregivers often report significant difficulty in navigating the complex system of rehabilitation care to obtain the needed medical, mental health, educational and social services. Adverse health status of the primary caregivers could interfere with the ability to meet the needs of the care receiver, and might affect the rehabilitation. ${ }^{3}$ An assessment of quality of life among caregivers is important for the interventions targeted at rehabilitation. This assumes importance in rural areas having limited access to rehabilitation services. Hence this study is carried out with the objective of assessing quality of life of caregivers of persons attending a rehabilitation centre.

\section{METHODS}

A Hospital based cross sectional study was conducted during the period July 2014 to December 2014. Approval was obtained from the ethics committee of JSS Medical College and Vivekananda Memorial Hospital, SVYM. Required permission was obtained from the authorities of the hospital to conduct the study. Study subjects were 100 caregivers of persons registered under "Chaitanya Vahini" programme run by SVYM Hospital, Sargur, H.D.Kote taluk. Care givers of bed ridden/seriously ill patients were excluded from the study. Sample size was estimated by using the formula $\left(n=4 \mathrm{pq} / 1^{2}\right)$, where $\mathrm{p}=$ prevalence of disability as per NSSO-2002 $=2.2 \%{ }^{2}$, with an absolute allowable error of $3 \%, \mathrm{n}=95.6$ rounded off to 100 study care givers. Prior informed consent in the local language Kannada was obtained from all the caregivers who were included in the study. For those who were illiterates, the consent was read out and explained to them in their language and consent was obtained by taking their thumb impression in the presence of a witness.

A pre tested and structured questionnaire was administered to all the care givers and the data was collected. Socio-demographic profile, WHOQOL-BREF an abbreviated 26-item version of the WHOQOL-100 was included in the proforma ${ }^{4}$. Data thus obtained was coded and entered into Microsoft excel and analysed using SPSS 22.0 Version. Descriptive statistical analysis, $\mathrm{t}$ test and chi-square test were applied. The statistical significance level was taken as $\mathrm{p}<0.05$.

\section{RESULTS}

Table 1 shows association between physical domain of QOL and marital status of caregivers which was found to be statistically significant $(\mathrm{p}<0.05)$. Majority of subjects who were married were having a low mean QOL score. It also shows association between earning status of caregivers and physical domain of QOL which was found to be statistically significant $(\mathrm{P}<0.05)$.

Table 2 reveals association between psychological domain of QOL and marital status of care givers which was statistically significant $(\mathrm{p}<0.05) .90 .9 \%$ of widows and $85.7 \%$ of widowers had lower scores. $52.5 \%$ of married caregivers were found to have lower QOL score.

Table 1: Factors affecting physical domain of QOL.

\begin{tabular}{|c|c|c|c|}
\hline $\begin{array}{l}\text { Marital } \\
\text { status }\end{array}$ & $\begin{array}{l}\text { Below } \\
\text { mean score }\end{array}$ & $\begin{array}{l}\text { Above } \\
\text { mean score }\end{array}$ & p-value \\
\hline a) Unmarried & $0(0 \%)$ & $4(100 \%)$ & \multirow{6}{*}{0.001} \\
\hline b) Married & $42(53.8 \%)$ & $36(46.15 \%)$ & \\
\hline c) Separated & $0(0 \%)$ & $1(100 \%)$ & \\
\hline $\begin{array}{l}\text { d) Living as } \\
\text { married }\end{array}$ & $1(100 \%)$ & $0(0 \%)$ & \\
\hline e) Widow & $11(100 \%)$ & $0(0 \%)$ & \\
\hline f) Widower & $4(75 \%)$ & $1(25 \%)$ & \\
\hline \multicolumn{4}{|c|}{ Caregivers' income } \\
\hline a) Earner & $29(70.7 \%)$ & $12(29.3 \%)$ & \multirow{2}{*}{0.032} \\
\hline b) Non earner & $29(49.1 \%)$ & $30(50.9 \%)$ & \\
\hline
\end{tabular}

Table 2: Factors affecting psychological domain of QOL.

\begin{tabular}{|c|c|c|c|}
\hline $\begin{array}{l}\text { Marital } \\
\text { status }\end{array}$ & $\begin{array}{l}\text { Below } \\
\text { mean score }\end{array}$ & $\begin{array}{l}\text { Above } \\
\text { mean score }\end{array}$ & p-value \\
\hline a) Unmarried & $0(0 \%)$ & $3(100 \%)$ & \multirow{6}{*}{0.006} \\
\hline b) Married & $41(52.5 \%)$ & $37(47.5 \%)$ & \\
\hline c) Separated & $0(0 \%)$ & $1(100 \%)$ & \\
\hline $\begin{array}{l}\text { d) Living as } \\
\text { married }\end{array}$ & $1(100 \%)$ & $0(0 \%)$ & \\
\hline e) Widow & $10(90.9 \%)$ & $1(9.1 \%)$ & \\
\hline f) Widower & $6(85.7 \%)$ & $1(14.3 \%)$ & \\
\hline
\end{tabular}

Table 3 reveals association between social domain of QOL and age of care givers. People above the age of 36 years were having lower QOL score compared to those in the younger age category. Also shows association between social domain of QOL and marital status of caregivers which was found to be significant statistically $(\mathrm{p}<0.05)$. Caregivers who were unmarried, separated, widow and widower were having lower QOL. It also reveals association between literacy status of care givers and social domain of QOL which is significant statistically $(\mathrm{p}<0.05)$. Illiterate caregivers had lower QOL score in comparison to who had primary education. It reveals association between social domain of QOL and family size which was found to be significant statistically $(\mathrm{p}<0.05)$.

Caregivers in a family of more than 6 persons have lower mean score compared to other families which was found to be statistically significant $(\mathrm{p}<0.05)$. Table also shows social domain of QOL was affected by the earning capacity of caregivers. Non-earning caregivers were having lower QOL score compared to caregivers who had some source of income which was found to be statistically significant $(\mathrm{p}<0.05)$. Association between type of disability the caregiver was dealing and the social domain of QOL which was significant statistically $(\mathrm{p}<0.05)$.Association between social domain of QOL and 
duration of care was found to be significant statistically $(\mathrm{p}<0.05)$.

Table 3: Factors affecting social domain of QOL.

\begin{tabular}{|c|c|c|c|}
\hline Age (years) & $\begin{array}{l}\text { Below mean } \\
\text { score }\end{array}$ & $\begin{array}{l}\text { Above mean } \\
\text { score }\end{array}$ & $\begin{array}{l}\text { p- } \\
\text { value }\end{array}$ \\
\hline Below 18 & $1(20 \%)$ & $4(80 \%)$ & \multirow{5}{*}{0.02} \\
\hline $19-25$ & $5(33.3 \%)$ & $10(66.6 \%)$ & \\
\hline $26-35$ & $10(35.7 \%)$ & $18(64.3 \%)$ & \\
\hline $36-45$ & $17(62.9 \%)$ & $10(37.1 \%)$ & \\
\hline Above 45 & $16(64 \%)$ & $9(36 \%)$ & \\
\hline \multicolumn{4}{|l|}{ Marital status } \\
\hline Unmarried & $2(50 \%)$ & $2(50 \%)$ & \multirow{6}{*}{0.000} \\
\hline Married & $30(38.4 \%)$ & $48(61.6 \%)$ & \\
\hline Separated & $1(100 \%)$ & $0(0 \%)$ & \\
\hline $\begin{array}{l}\text { Living as } \\
\text { married }\end{array}$ & $1(100 \%)$ & $0(0 \%)$ & \\
\hline Widow & $11(100 \%)$ & $0(0 \%)$ & \\
\hline Widower & $4(80 \%)$ & $1(20 \%)$ & \\
\hline \multicolumn{4}{|l|}{ Education } \\
\hline Illiterate & $34(65.3 \%)$ & $22(34.7 \%)$ & \multirow{4}{*}{0.006} \\
\hline $\begin{array}{l}\text { Primary } \\
\text { school }\end{array}$ & $14(36.8 \%)$ & $24(63.2 \%)$ & \\
\hline $\begin{array}{l}\text { Secondary } \\
\text { school }\end{array}$ & $1(33.3 \%)$ & $29(66.7 \%)$ & \\
\hline $\begin{array}{l}\text { Above } \\
\text { secondary } \\
\text { school }\end{array}$ & $0(0 \%)$ & $3(100 \%)$ & \\
\hline \multicolumn{4}{|l|}{ Family size } \\
\hline 2 & $22(46.8 \%)$ & $25(53.2 \%)$ & \multirow{3}{*}{0.021} \\
\hline $3-5$ & $20(44.4 \%)$ & $25(55.6 \%)$ & \\
\hline$>6$ & $7(87.5 \%)$ & $1(12.5 \%)$ & \\
\hline \multicolumn{4}{|c|}{ Caregivers' income } \\
\hline Earner & $23(46.9 \%)$ & $26(53.1 \%)$ & \multirow{2}{*}{0.017} \\
\hline Non earner & $36(70.5 \%))$ & $15(29.5 \%)$ & \\
\hline \multicolumn{4}{|l|}{ Disability } \\
\hline $\begin{array}{l}\text { Cerebral } \\
\text { palsy }\end{array}$ & $6(27.2 \%)$ & $16(72.8 \%)$ & \multirow{6}{*}{0.009} \\
\hline Hearing loss & $1(12.5 \%)$ & $7(87.5 \%)$ & \\
\hline $\begin{array}{l}\text { Physically } \\
\text { handicapped }\end{array}$ & $25(60.9 \%)$ & $16(39.1 \%)$ & \\
\hline $\begin{array}{l}\text { Mentally } \\
\text { retarded }\end{array}$ & $9(64.2 \%)$ & $5(35.8 \%)$ & \\
\hline Blind & $4(36.3 \%)$ & $7(63.7 \%)$ & \\
\hline Stroke & $4(100 \%)$ & $0(0 \%)$ & \\
\hline \multicolumn{4}{|c|}{ Duration of care giving } \\
\hline Below 5 years & $15(30.6 \%)$ & $34(69.4 \%)$ & \multirow[b]{2}{*}{0.020} \\
\hline $\begin{array}{l}\text { Above } 5 \\
\text { years }\end{array}$ & $26(50.9 \%)$ & $25(49.1 \%)$ & \\
\hline
\end{tabular}

Table 4 reveals association between environmental domain of QOL and marital status of caregivers observed to be significant statistically $(\mathrm{p}<0.05)$. $58.9 \%$ of illiterate caregivers were found to have lower QOL score and $63.2 \%$ of care givers who had primary school education had higher QOL score. Table shows statistical significant association between environmental domain of QOL and relation to care receiver $(\mathrm{p}<0.05)$. Association between environmental domain of QOL and duration of care giving was significant statistically $(\mathrm{p}<0.05)$.

Table 4: Factors affecting environmental domain of QOL.

\begin{tabular}{|c|c|c|c|}
\hline $\begin{array}{l}\text { Marital } \\
\text { Status }\end{array}$ & $\begin{array}{l}\text { Below } \\
\text { mean score }\end{array}$ & $\begin{array}{l}\text { Above } \\
\text { mean score }\end{array}$ & p-value \\
\hline Unmarried & $1(25 \%)$ & $3(75 \%)$ & \multirow{6}{*}{0.005} \\
\hline Married & $33(42.3 \%)$ & $45(57.7 \%)$ & \\
\hline Divorced & $0(0 \%)$ & $1(100 \%)$ & \\
\hline Separated & $1(100 \%)$ & $0(0 \%)$ & \\
\hline Widow & $10(90.9 \%)$ & $1(9.1 \%)$ & \\
\hline Widower & $6(75 \%)$ & $2(25 \%)$ & \\
\hline \multicolumn{4}{|l|}{ Education } \\
\hline Illiterate & $33(58.9 \%)$ & $23(41.1 \%)$ & \multirow{4}{*}{0.010} \\
\hline $\begin{array}{l}\text { Primary } \\
\text { school }\end{array}$ & $14(36.8 \%)$ & $24(63.2 \%)$ & \\
\hline $\begin{array}{l}\text { Secondary } \\
\text { school }\end{array}$ & $0(0 \%)$ & $3(100 \%)$ & \\
\hline $\begin{array}{l}\text { Above } \\
\text { secondary } \\
\text { school }\end{array}$ & $1(33.3 \%)$ & $2(66.7 \%)$ & \\
\hline \multicolumn{4}{|c|}{ Relation to care receiver } \\
\hline Parents & $34(54.8 \%)$ & $28(45.2 \%)$ & \multirow{4}{*}{0.025} \\
\hline Spouse & $11(50 \%)$ & $11(50 \%)$ & \\
\hline Offspring & $0(0 \%)$ & $3(100 \%)$ & \\
\hline Others & $3(23.7 \%)$ & $10(76.3 \%)$ & \\
\hline \multicolumn{4}{|c|}{ Duration of care giving } \\
\hline Below 5 years & $35(57.3 \%)$ & $26(42.7 \%)$ & \multirow[b]{2}{*}{0.022} \\
\hline $\begin{array}{l}\text { Above } 5 \\
\text { years }\end{array}$ & $13(33.3 \%)$ & $26(66.7 \%)$ & \\
\hline
\end{tabular}

Table 5 shows that as the duration of care giving increases there is a deterioration of physical and social domains of QOL. This is reflected as statistically significant negative correlation between duration of care giving and QoL domains i.e. physical \& social.

Table 5: Correlation between domains of QOL and duration of care.

\begin{tabular}{|lll|}
\hline Domains & R & p \\
\hline Physical & -0.250 & 0.012 \\
\hline Psychological & -0.013 & 0.899 \\
\hline Social & $-0.274^{* * *}$ & 0.006 \\
\hline Environmental & 0.192 & 0.055 \\
\hline
\end{tabular}

\section{DISCUSSION}

\section{Mean $Q O L$}

Total 100 caregivers were interviewed and the mean Quality of Life of these caregivers was 71.97. Mary Lícia de Lima and Jair Lício Ferreira Santos established in their 
study done in Brazil that being a caregiver affects the QOL adversely. ${ }^{5}$

\section{QOL according to age}

In this study it was observed that, Social domain of QOL was found to be significantly associated with age. $(\mathrm{P}=0.002)$ Pedro Schestatsky, et al. observed similar results in their study in Brazil. Environment, Physical and Psychological domains of QOL had been found not to be significantly affected by age, non-significant with age, which is in line with the results of the present study. ${ }^{6}$ In a study done by Abdel W Awadalla in 2007, it was found that caregivers with higher age had higher QOL score. ${ }^{7}$

\section{QOL according to sex}

In the present study the mean QOL score was almost same among males and females and there was no statistically significant difference in these groups ( $p>0.05)$. Diego Mugno had concluded in his study that mothers had lower QOL score compared to fathers. ${ }^{8}$

\section{QOL according to marital status}

In present study it was observed that caregivers who are married had better QOL score than other caregivers. It was statistically significant in all 4 domains. It may be attributed to the fact that majority of caregivers are married in present study. Similar results were found in a study done by Asmahan F Alshubaili and Jude U Ohaeri who reported that caregivers who were married had higher QOL score. ${ }^{9}$

\section{QOL according to type of family}

In the present study mean QOL of caregivers did not vary significantly with type of family. Pedro Schestatsky et al observed positive co-relation between physical domain score and number of people living in same house in Brazil. ${ }^{6}$

\section{QOL according to educational level}

In the present study it was observed that caregivers with higher education had better QOL as compared to caregivers with lesser education. This finding was statistically significant in social and environment domain $(p<0.05)$. Rebecca $G$ concluded in her study that education was significantly associated with QOL score of caregivers. ${ }^{10}$

Education was also found affecting QOL score in a study conducted by Abdel W Awadalla. ${ }^{7}$

Contrary to the above findings, Asmahan F Alshubaili and Jude U Ohaeri observed in their study that lower education was associated with lower QOL score. ${ }^{9}$ Daniel Fu Keung Wong observed that caregivers with lower educational status had more difficulties and lower score of QOL. ${ }^{11}$ Ruzanna ZamZam and Marhani Midin noted in their study that higher educational status was associated with higher QOL score. ${ }^{12}$

\section{QOL according to occupational status}

In the present study the mean QOL was lower among homemakers and daily-wage labourers (coolies) in comparison to caregivers engaged in other occupation. This was statistically significant ( $\mathrm{p}$-value $<0.02)$.

Asmahan F Alshubaili and Jude U Ohaeri observed in their study that caregivers engaged in higher skill work had higher QOL score. ${ }^{7}$

\section{QOL according to earning capacity of caregiver}

The study revealed that the caregivers who were earning had lower QOL score compared to those who were not earning. It was found statistically significant in physical and environment domain ( $\mathrm{p}$-value=0.032).

\section{QOL according to total family income}

In present study it was found that caregivers with lower family income had lower QOL score compared to caregivers with higher family income. It was found statistically significant in physical, psychological and environment domain. Asmahan F Alshubaili and Jude U Ohaeri in their study observed that caregiver's unemployment and hence total family income was associated with lower QOL. ${ }^{9}$

\section{QOL according to family size}

The present study revealed that caregivers with a family size of 3 to 5 members had higher QOL score and was statistically significant in social domain.

\section{QOL according to relation of caregiver to disabled person}

In present study it was observed that mothers and fathers had lower QOL score compared to other relations and was statistically significant in environment domain ( $p$ value $=0.025$ ). Diego Mugno observed in his study that mothers had lower QOL than fathers. ${ }^{8}$ Asmahan $F$ Alshubaili and Jude U Ohaeri observed in their study that parents had higher QOL score than the spouse caregivers. ${ }^{9}$ Abdel W Awadalla also had similar findings in his study conducted in Kuwait. ${ }^{7}$

\section{QOL according to type of disability}

The present study revealed that the people who were caregivers for physically handicapped persons had significantly lower QOL score that those of people caring for other disabilities. 


\section{QOL according to duration of care giving}

In present study it was observed that people who were caregivers for more than 5 years had lower QOL score compared to others. It was found to be statistically significant in social domain. In a study conducted by Abdel W Awadalla it was observed that duration of care giving was not associated with QOL of caregivers. ${ }^{7}$ Ruzanna ZamZam and Marhani Midin observed in their study that duration of caregiving was significantly associated with QOL score. It is in line with findings of our study. ${ }^{12}$

Eloise H. Tew and Sharon L observed that lower QOL scores were associated with duration of caregiving. ${ }^{13}$ Sandeep Grover's study findings suggest that longer duration of care giving was associated with lower QOL scores. $^{14}$

\section{Correlation between social domain of $Q O L$ and duration of care}

As the duration of care giving increases there is a deterioration of physical and social domains of QOL. This is reflected as statistically significant negative correlation between duration of care giving and QOL i.e. physical and social domains.

\section{CONCLUSION}

Mean domain score for physical, psychological, social and environmental domains were 88.12, 72.48, 33.08 \& 94.2 respectively. There were significant difference in QoL score according to marital status, caregiver's income, educational levels, family size, type of disability, duration of care giving and relation to disabled persons. In conclusion, the quality of life is a multidimensional concept. This assumes more importance in rural areas having poverty \& limited access to rehabilitation services. Therefore intervention targeted rehabilitation approach is required. Social assistance from governmental and non-governmental organizations to both care givers and disabled people are need of the hour to improve their Quality of Life.

\section{Limitation}

Hospital based study; hence the results cannot be generalized to the population. More female study subjects in comparison to males.

\section{ACKNOWLEDGMENT}

We would like to thank SVYM organization, Sargur and their health workers for their help to carry out data collection. We would also like to express my gratitude to all the caregivers who took time from their busy schedule and made the study possible.
Funding: No funding sources

Conflict of interest: None declared

Ethical approval: The study was approved by the Institutional Ethics Committee

\section{REFERENCES}

1. World Health Organization. Document A29/INFDOCI/1, Geneva, World Health Organization. 1976.

2. National Sample Survey Organization. Disabled Persons in India: NSS 58th Round. Report `No. 485. New Delhi: Ministry of Statistics and Program Implementation, Government of India. 2002.

3. WHO. Meeting Report on the development of guidelines for Community Based Rehabilitation (CBR) programmers. (1st and 2nd November 2004, Geneva, Switzerland); Final Draft. 2005.

4. The WHOQOL Group. The World Health Organization Quality of Life Assessment (WHOQOL): position paper from World Health Organization. Soc. sci. med. 1995;41:1403.

5. Lima ML. Quality of life of individuals with stroke and their caregivers in a city of Triângulo Mineiro. Rev B ras Epidemiol a Pr -jun. 2014;453-64.

6. Schestatsky P. Quality of life in a Brazilian sample of patients with Parkinson's disease and their caregivers. Rev Bras Psiquiatr. 2006;28(3):209-11.

7. Awadalla AW, Ohaeri JU, Gholoum A, Khalid AO, Hamad HMA, Jacob A. Factors associated with quality of life of outpatients with breast cancer and gynecologic cancers and their family caregivers: a controlled study. BMC Cancer. 2007;7:102.

8. Mugno D, Ruta L, D'Arrigo VG, Mazzone L. Impairment of quality of life in parents of children and adolescents with pervasive developmental disorder. Health and Quality of Life Outcomes. 2007;5:22.

9. Alshubaili AF, Ohaeri JU, Awadalla AW, Mabrouk AA. Family caregiver quality of life in multiple sclerosis among Kuwaitis: A controlled study. BMC Health Services Research. 2008;8:206.

10. Logsdon RG, Gibbons LE, McCurry SM, Teri L. Journal of Mental Health and Aging. 1999;5(1).

11. Wong DFK, Lam AYK, Chan SK, Chan SF. Quality of life of caregivers with relatives suffering from mental illness in Hong Kong: roles of caregiver characteristics, caregiving burdens, and satisfaction with psychiatric services. Health and Quality of Life Outcomes. 2012;10:15.

12. ZamZam. Schizophrenia in Malaysian families: A study on factors associated with quality of life of primary family caregivers. International Journal of Mental Health Systems. 2011;5:16.

13. Tew EH, Naismith SL, Pereira M, Lewis SJG. Quality of Life in Parkinson's disease Caregivers: The Contribution of Personality Traits. BioMed Research International Volume. Article ID 151872. 2013. 
14. Grover S, Dutt A. Perceived burden and quality of life of caregivers in obsessive-compulsive disorder. Psychiatry and Clinical Neurosciences. 2011;65:416-22.
Cite this article as: Boralingiah $\mathrm{P}$, Baby A, Kulkarni P, Ramachandrappa SM, Manjunath R. Assessment of quality of life among caregivers of persons with permanent disabilities attending rehabilitation centre in H. D. Kote Taluq, Mysore district, Karnataka, India. Int J Community Med Public Health 2016;3:2645-50. 